\title{
ASSESSMENT OF BIOLOGICAL ACTIVITY OF FINE FRACTION FROM HÖGBYTORP LANDFILL BY OXYGEN CONSUMPTION MEASUREMENT
}

\author{
Merilyn Rang ${ }^{1}$ \\ Kaja Orupõld ${ }^{*}$ \\ Mait Kriipsalu ${ }^{1}$ \\ William Hogland $^{2}$ \\ ${ }^{l}$ Estonian University of Life Sciences, Tartu, Estonia \\ ${ }^{2}$ Linnaeus University, Kalmar, Sweden \\ *Corresponding author: kaja.orupold@emu.ee
}

\begin{abstract}
The objective of this study was to estimate the biological activity of fine fraction excavated from the Ragn-Sells AB landfill site at Högbytorp (40 km north-west of Stockholm, Sweden). For this purpose cumulative oxygen consumption (respiration activity) of the fine fraction was measured with OxiTop® system. The Högbytorp landfill was sampled from 4 test-pits, each from 4 different depths. Altogether 16 samples were gathered, screened $(<10 \mathrm{~mm})$ and analysed in the laboratory. The mean oxygen consumption of fine fraction during 7 days was $7.6 \pm 4.1$ and during 4 days $5.6 \pm 3.0 \mathrm{mgO}_{2} \mathrm{~g}^{-1}$. The variability of respiration activity between fine fraction samples from the Högbytorp landfill is discussed. The results are compared with the proposed value for material suitable for biocover construction and also with landfill acceptance criteria for waste set in a few countries.
\end{abstract}

\section{KEYWORDS}

Landfill mining, fine fraction, biological activity, oxygen consumption

\section{INTRODUCTION}

Enormous amount of waste in landfills can be regarded as a potential source for energy and raw materials and for that reason there is a growing interest in utilization of deposited materials, usually referred to as landfill mining. Beside of valuable raw material, landfills contain huge amount of fine soil-like fraction, which, depending on the landfill, may account to more than $50 \%$ of total mass of the excavated material [1-3]. Fine fraction has been recommended as potential material to substitute soil, for instance for landfill cover and biocover construction $[3,4]$, or it may be classified as waste that must be backfilled, creating extra costs. In both cases characterization of fine fraction is inevitable, being particularly decisive for its beneficial usage $[3,5,6]$. 


\title{
Linnaeus ECO-TECH '14
}

\author{
Kalmar, Sweden, November 24-26, 2014
}

In addition to physico-chemical characterization, the parameters describing biological activity/stability of waste have been increasingly studied during recent years [7-9]. Respiration activity, amount of oxygen consumed by microbial processes at defined conditions per gram of dry mass, has been found to be suitable parameter for characterizing stability of wastes and added as acceptance criteria for the landfilling of waste into national legislations of Germany and Austria [10]. The oxygen consumption is also considered as one of the most important criteria for estimation of material suitability for biocover construction [11].

The objective of this study was to estimate the biological activity of fine fraction excavated from the Ragn-Sells AB landfill site at Högbytorp (Sweden).

\section{METHODS}

\subsection{Site description and sampling}

The landfill mining was carried out on Ragn-Sells AB landfill site at Högbytorp, situated 40 $\mathrm{km}$ north-west of Stockholm $\left(60^{\circ} 32^{\prime} \mathrm{N}, 17^{\circ} 37^{\prime}\right.$ E, Sweden) where the prevailing climate is cold temperate and mean annual precipitation $600 \mathrm{~mm}$ [12]. The Högbytorp landfill was established in 1964, occupies an area of around 30 hectares and contains municipal as well as industrial wastes.

The Högbytorp landfill was sampled from 4 randomly chosen points. Four test-pits $(\mathrm{H} 1, \mathrm{H} 2$, H3, H4) were excavated down to approximately $4 \mathrm{~m}$ depth. From each pit waste was sampled from 4 depth interval (B1 $0-1 \mathrm{~m}, \mathrm{~B} 21-2 \mathrm{~m}, \mathrm{~B} 32-3 \mathrm{~m}, \mathrm{~B} 43-4 \mathrm{~m}$ ) by an excavator with a bucket size of $1 \mathrm{~m}^{3}$. The excavated material originated from temporary storage cell, maximum 4 years old. Waste cell was covered by a thin layer of cover material and contained mostly commercial waste and no household waste.

The waste samples were sorted and finally sieved. The undersize fraction $<10 \mathrm{~mm}$, further referred to as fine fraction, was under investigation in this study. Altogether 16 fine fraction samples were gathered and analysed in the laboratory.

\subsection{Laboratory analyses}

The oxygen consumption of fine fraction was determined using manometric respirometric OxiTop® system (WTW, Germany) according to the manufacture's recommendations [13]. The measurements were performed in 1 litre air-tight container with 50-60 g of fresh sample. The optimum water content of fine fraction samples were not adjusted, the samples were analysed with the moisture content they were excavated from the landfill. The produced $\mathrm{CO}_{2}$ was removed by absorber $(2 \mathrm{M} \mathrm{NaOH})$, the resulting negative pressure was a measure of oxygen consumption. To maintain aerobic conditions throughout the experiment the measuring containers were opened and vented when pressure decrease inside the containers exceeded $100 \mathrm{hPa}$. The cumulative oxygen consumption during 4 and 7 days, reflecting the "basal respiration" of the fine fraction, was measured and expressed as amount of oxygen consumed per $\mathrm{g}$ dry matter $\left(\mathrm{mgO}_{2} \mathrm{~g}^{-1}\right)$ of the initial material. All measurements were performed in triplicates at $20^{\circ} \mathrm{C}$ in a climate chamber (Sanyo MLR-351H, Sanyo Electric, Japan) in dark. 


\section{Linnaeus ECO-TECH '14}

Kalmar, Sweden, November 24-26, 2014

Dry matter was measured after drying the samples overnight at $105^{\circ} \mathrm{C}$. Organic matter was determined by loss on ignition at $550^{\circ} \mathrm{C}$. For measurement of $\mathrm{pH}$ and electrical conductivity $(\mathrm{pH} / \mathrm{Cond} 340 \mathrm{i}$. WTW), $5 \mathrm{~g}$ fine fraction and $50 \mathrm{ml}$ distilled water $(1: 10 \mathrm{w} / \mathrm{v})$ were mixed and shaken on an orbital shaker (140 rpm) for $1 \mathrm{~h}$.

\section{RESULTS AND DISCUSSION}

The results of the oxygen uptake measurements are presented in Figure 1 and Table 1. Sixteen fine fraction samples analysed can be characterized with the mean 7-day oxygen consumption of $7.6 \mathrm{mgO}_{2} \mathrm{~g}^{-1}$ and median of $7.7 \mathrm{mgO}_{2} \mathrm{~g}^{-1}$. Among samples the highest oxygen consumption was seen in the pit 1 (H1) in samples from the upper layers (B1 and B2). The smallest oxygen consumption was measured in the sample from the deepest (B4) layer of the pit $3(\mathrm{H} 3)$. The reason for low oxygen consumption in samples H3B3 and H3B4 is not clear. The adjustment of water content before measurements did not considerable increase oxygen consumption in those samples. The low oxygen uptake could be explained with the presence of compounds inhibiting microbial activity.

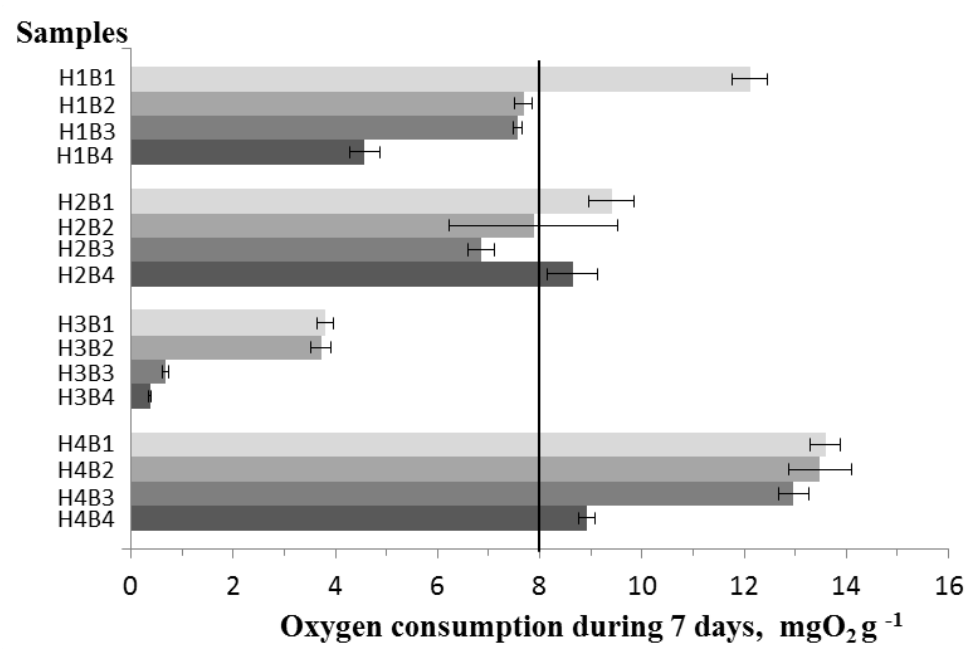

Figure 1. Cumulative oxygen consumption during 7 days of different fine fraction samples excavated from Högbytorp landfill. The error bars show standard deviations, the vertical line the limit proposed by Huber-Humer [11] for material suitable for biocover construction.

Table 1. Means \pm standard deviations of cumulative oxygen consumption of fine fraction by different test pits and depths.

\begin{tabular}{|c|c|c|c|c|c|}
\hline \multicolumn{6}{|c|}{ Oxygen consumption during 7 days, $\mathrm{mgO}_{2} \mathrm{~g}^{-1}$} \\
\hline & Test-pits & & & & \multirow[b]{2}{*}{ Mean by layers } \\
\hline Layers & H1 & $\mathrm{H} 2$ & $\mathrm{H} 3$ & $\mathrm{H} 4$ & \\
\hline B1 & $12.1 \pm 0.3$ & $9.4 \pm 0.4$ & $3.8 \pm 0.2$ & $13.6 \pm 0.3$ & $5.6 \pm 4.0$ \\
\hline B2 & $7.9 \pm 0.2$ & $7.9 \pm 0.2$ & $3.7 \pm 0.2$ & $13.5 \pm 0.6$ & $7.0 \pm 5.0$ \\
\hline B3 & $7.6 \pm 0.1$ & $6.8 \pm 0.3$ & $0.7 \pm 0.1$ & $13.0 \pm 0.3$ & $8.2 \pm 4.0$ \\
\hline B4 & 4. $6 \pm 0.3$ & $8.6 \pm 0.5$ & $0.4 \pm 0.0$ & $8.9 \pm 0.2$ & $9.7 \pm 4.3$ \\
\hline Mean by pits & $8.0 \pm 3.1$ & $8.2 \pm 1.1$ & $2.1 \pm 1.9$ & $12.2 \pm 2.2$ & \\
\hline
\end{tabular}




\section{Linnaeus ECO-TECH '14}

Kalmar, Sweden, November 24-26, 2014

The results in Table 1 show that samples from the same landfill can differ by more than 30 times in oxygen consumption. The results vary up to 6 times if compare the means of different test-pits. The Anova single factor analysis showed statistically significant $(p<0.05)$ differences between pits. The mean values calculated per layer varied less than that of pits. In general, the fine fraction sampled from the upper part of landfill had higher respiration activity, indicating less stability.

Although the mean value of oxygen consumption during 7 days for studied fine fraction was under the limit value $\left(\leq 8 \mathrm{mgO}_{2} \mathrm{~g}^{-1}\right)$ proposed for the material suitable for biocover construction [11], half of the studied samples exceeded this criterion (Figure 1). Higher organic matter content is favourable for biocover, but material suitable for biocover must be stable and mature. The materials which are not stable may cause oxygen depletion in biocover, resulting in oxygen deficiency for methane oxidation or even production of methane if anaerobic conditions develop.

Oxygen consumption during 4 days (respiration activity $\mathrm{AT}_{4}$ ) is the parameter limited as waste acceptance criteria for assessment the stability of waste in Germany $\left(5 \mathrm{mgO}_{2} \mathrm{~g}^{-1}\right)$ and Austria $\left(7 \mathrm{mgO}_{2} \mathrm{~g}^{-1}\right)$ [10] and discussed in European legislation draft documents $\left(10 \mathrm{mgO}_{2} \mathrm{~g}^{-1}\right)$ [14]. The mean 4-day oxygen consumption of fine fraction analysed in this study was $5.6 \pm 3.0 \mathrm{mgO}_{2} \mathrm{~g}^{-1}$ indicating that the mean sample of fine fraction should not accomplish the waste stability limit set in Germany.

The mean values of basic characteristics of fine fraction from Högbytorp are presented in Table 2. The content of organic matter, measured as loss on ignition, in fine fraction formed in average $16.5 \%$ of dry matter, the results varied from 11.0 to $23.7 \%$. However, the Pearson correlation analysis did not reveal the statistically significant correlation between oxygen uptake and organic matter content in samples.

Table 2. Means \pm standard deviations (SD) of some physico-chemical characteristics of fine fraction samples excavated from Högbytorp landfill.

\begin{tabular}{ll}
\hline Parameter & Mean \pm SD \\
\hline Dry matter, \% & $75.6 \pm 3.4$ \\
Organic matter, \% & $16.5 \pm 3.6$ \\
pH & $7.72 \pm 0.13$ \\
Electrical conductivity, $\mathrm{mS} / \mathrm{cm}$ & $3.43 \pm 0.27$
\end{tabular}

\section{CONCLUSIONS}

The objective of this study was to characterize biological activity of fine soil-like fraction recovered from landfill and to assess the limitations associated with the use or disposal of this material. Samples were collected from the Högbytorp landfill in Sweden and analysed for oxygen consumption (respiration activity).

The results showed high variability in oxygen consumption between fine fraction samples excavated from different locations on the landfill. However, the mean sample of fine fraction 


\section{Linnaeus ECO-TECH '14}

Kalmar, Sweden, November 24-26, 2014

can be considered stable for landfilling or for application in landfill biocover construction. While the current study addressed only on biological activity, more detailed site-specific study to evaluate the risk associated with the application of the fine fraction is obligatory. The leaching of metals and organic pollutants and ecotoxicity of the leachate were not evaluated, but must be certainly investigated prior using the fine fraction.

\section{ACKNOWLEDGEMENTS}

The authors acknowledge the support from the Swedish Institute - SI. We are grateful for the help for Anders Kihl and Ragn-Sells AB. Also many thanks go to Högbytorp laboratory personnel.

\section{REFERENCES}

[1] Hogland, W., Marques, M., Nimmermark, S., 2004. Landfill mining and waste characterization: a strategy for remediation of contaminated areas. Journal of Material Cycles and Waste Management 6, 119-124.

[2] Masi, S., Caniani, D., Grieco, E., Lioi, D.S., Mancini, I.M., 2014. Assessment of the possible reuse of MSW coming from landfill mining of old open dumpsites. Waste Management 34, 702-710.

[3] Quaghebeur, M., Laenen, B., Geysen, D., Nilesen, P., Pontikes, Y., Gerven, T.V., Spooren, J., 2013. Characterization of landfilled materials: screening of the enhanced landfill mining potential. Journal of Cleaner Production 55, 72-83.

[4] Hogland, W., 2002. Remediation of an old landfill site. Soil analysis, leachate quality and gas production. ESPR - Environ Sci \& Pollut Res 9 (Special Issue 1), 50-54.

[5] Jain, P., Kim, H., Townsend, G., 2005. Heavy metal content in soil reclaimed from a municipal solid waste landfill. Waste Management 25, 25-35.

[6] Kaartinen, T., Sormunen, K., Rintala, J., 2013. Case study on sampling, processing and characterization of landfilled municipal solid waste in the view of landfill mining. Journal of Cleaner Production 55, 56-66.

[7] Barrena, R., d’Imporzano, G., Ponsá, S., Gea, T., Artola, A., Vázquez, F., Sánchez, A., Adani, F., 2009. In search of a reliable technique for the determination of the biological stability of the organic matter in the mechanical-biological treated waste. Journal of Hazardous Materials 162, 1065-1072.

[8] Binner, E., Böhm, K., Lechner, P., 2012. Large scale study on measurement of respiration activity (AT4) by Sapromat and OxiTop. Waste Management 32, 1752-1759.

[9] Wagland, S. T., Tyrrel, S. F., Godley A. R., Smith, R., 2009. Test methods to aid in the evaluation of the diversion of biodegradable municipal waste (BMW) from landfill. Waste Management 29, 1218-1226.

[10] Cossu, R., Raga, R., 2008. Test methods for assessing the biological stability of biodegradable waste. Waste Management 28, 381-388.

[11] Huber-Humer, M., Röder, S., Lechner, P., 2009. Approaches to assess biocover performance on landfills. Waste Management 29, 2092-2104.

[12] Östman, M., 2008. Ageing landfills -development and processes. Doctoral Thesis. Swedish University of Agricultural Sciences, Uppsala, Sweden.

[13] WTW Field Report, 2007. $\mathrm{AT}_{4}$ Respiration. Biodegradability of the dry residue of the original substance. WTW, Germany.

[14] European Commission, 2001. Working document, Biological treatment of biowaste, 2nd draft. URL: www.compost.it/www/pubblicazioni_on_line/biod.pdf (12.09.2014) 